\title{
GAME AS A PHENOMENON IN KYRGYZ FAMILY TRADITIONS
}

\begin{abstract}
The relevance of the philosophical understanding of the concept of "game" is caused by the great interest in this phenomenon from the humanities and mathematical sciences (game theory). The subject of research is the socio-philosophical aspects of the game in the Kyrgyz family traditions. The purpose of the study is to conduct a historical and philosophical analysis of the game component within the framework of the specifics of the Kyrgyz ethnos. In the course of our research, we identified such properties of a game as non-utilitarianism, irrationality, the presence of rules, aesthetics, and the predominance of the child over the adult. We conclude that the nomadic and rhizomatic structure of Kyrgyz society played a decisive role in the sustainability of the transmission of family traditions through the game component. The author analyzed the game component of social matter during the main historical periods of the Kyrgyz ethnos and stages of psychosocial development. The following methods were used conceptual analysis, synchronic and diachronic method, comparative-historical approach, network methodology with elements of the poststructuralist topological approach.
\end{abstract}

Keywords: game, tradition, culture, nomadism, globalization, rhizome, space.

\section{Introduction}

The growing interest in the concept of "game" within a wide range of humanities (psychology, pedagogy, cultural studies, and history) actualizes the chosen research topic. Game aspects are being considered both as a teaching method and as a way to model certain situations with the aim of further forecasting and as an approach within psychotherapy. Such popularity of this concept gives rise to the need for its philosophical understanding. The most acute issue is the relevance of the chosen topic in connection with the destruction of the extended family, traditional values in most modern societies. Kyrgyzstan is of particular interest in this context because it has turned into one of the most unstable states in the post-Soviet space, where major political cataclysms occur - from democratic ethnocentrism to bloody inter-ethnic and intra-ethnic conflicts. Nevertheless, the country is relatively prosperous in preserving the family as the basic unit of society. In this regard, we need to turn our research gaze to the Kyrgyz family traditions and show how the game can successfully transmit the tradition, thereby opposing the world globalist tendencies. It is possible to single out various criteria for the success of a particular society. Still, one of the most relevant, in our opinion, is how long a given society could eventually survive. E. Burke (2004), as one of the founders of conservatism, identifies the following elements that ensure the longevity of this or that social organism: reliance on authority, prejudice and the church (p. 16). It seems to us that the game can also be included in this list as a tool for the transaction of family traditions.

We pay attention that within the framework of continental philosophical thought (the socalled postmodernism), a game becomes one of the key concepts. So J. Derrida (1998, pp. 118214) M. Foucault (2006, p. 56), J. Baudrillard (2020, p. 15), J. Deleuze (1996, pp. 15-83), R. Barthes (1975, p. 13) consider the philosophy as 
a kind of game with text, writing, meaning. This state of affairs requires a careful study of both the indicated concept itself and the social phenomena associated with it.

\section{Literature Review}

Despite its everyday presence and everyday obviousness, the game has been a stumbling block for the most talented thinkers for thousands of years since it requires incredible intellectual efforts to at least try to move them from their place using the methodological means and tools available at a given historical period. This collision provoked the formation of models and concepts of the game, which, although encompassing its characteristics and empirical manifestations, still did not achieve the harmonized value of the image of the game as an original way of human life in the world, and therefore as a unique way of human existence. There is no doubt that fragments or sketches of such a perfect image are present in many philosophical systems: from Plato (1997, p. 120) and M. Schiller (2016, p. 25) to J. Huizinga, J. Lacan (1998, pp. 63-82), M. Bakhtin (1965, pp. 10-11), G. Hesse (2002, pp. 76-104), G. Gadamer, R. Caillois (2001, pp. 18-74), O. Fink (2016, p. 212), P. Hutchinson (1984, pp. 5-26), O. Morgenstein and J. Neumann (2020, pp. 17-38), S. Rubinstein, Yu. Lotman (1998, pp. 37-42), D. Elkonin (1999, pp. 24-30), I. E. Berlyand (1992, p. 23), B. Miller (1997, p. 11), E. Berne (1996, pp. 8-28) and other researchers.

In logical and meaningful reflection on the subject of determining the nature, essence, genesis and phenomenology of the game, the middle of the twentieth century became a landmark: philosophical and humanitarian thought made a breakthrough in understanding the problem of the game component in human culture and everyday practice. Moreover, an attempt to explain this phenomenon made it possible to come closer to identifying the deep pre-reflex foundations of human existence and the ways of experiencing the reality of one's being inherent only to Homo sapiens. The pioneer in this problem-analytical context is the classic work of the Dutch theorist and cultural historian J. Huizinga (2014, pp. 764), which substantiates the exceptional primordial role of the game in all spheres and segments of human life and the general history of humanity.

The original philosophical concept of the game is offered by G. Gadamer (2008, pp. 136157), for whom it became an ontology based on a language - a medium of hermeneutic experience and the very human experience of the world in general. Only the actualization of this experience within the framework of philosophy, art and genesis of history makes it possible to understand and realize the truth that is inaccessible for knowledge. In general, the attainment of cognition is interpreted as a game that plays on its own. Since the carriers of experience are involved in the very process of delivering truth, and the hermeneutic proof is not a separate action but is the "act of the work itself", G. Gadamer considers the concept of play as a kind of dialogue that arises from circulation. Thus, the game is explained by the philosopher from the position of anti-subjectivism. This means that it fills with its essence, draws in the players and keeps them until the last moments of its completion. Therefore, the subject of the game is not the player but the game itself. The game is a subjective activity of a particular onto-phenomenological format, which makes it possible to gain experience and understand the process of connecting existing horizons and realizing the truth.

The famous German existentialist philosopher and psychiatrist $\mathrm{K}$. Jaspers considers the psychology of worldviews in the basic set of human attitudes. He substantiates the play attitude as a distinctive sphere of experience, which is opposite to seriousness within the framework of an active personality's attitude to the reincarnation of the world and characterized by activity, in contrast to ideological attitudes. The latter, however, is aimed at reality only in a certain fictional 
dimension; therefore, they can exist without any reality in a simple inner game of fantasies (Jaspers, 1971, p. 17).

The Soviet philosopher and psychologist S. Rubinstein, in the middle of the twentieth century, designated the ontological format of play as meaningful activity (as a set of conscious actions that are connected by one motive), which, being a "child of labour," consists in a person's ability not only to display but also to transform reality. "Appearing for the first time in play," writes S. Rubinstein (1989), "this is ability is forming. In the game, the first thing that is formed and manifested is the child's need to influence the world this is the main and central meaning of play" ( $p$. $65)$. So, for S. Rubinstein, play is "a way of realizing the needs and demands of a child within the limits of its capabilities," where the ability for object substitutions and new designations is determined by its immediate motivating meaning.

D. Uznadze (2000), putting forward the theory of functional tendency (p. 133), criticizes six, at that time, known theories of play:

1. K. Groos (2020, p. 15) is criticized, and mainly not because he considers the essence of play only in its main meaning - in preparing the child for a further serious activity, but in the fact that he only points to the meaning of the game, without identifying its source, without finding out the reasons that bring it to life and does not consider the motives that call for the game.

2. G. Spencer $(2019$, p. 98$)$ is criticized for the fact that he considers the source of the game over the strength of the personality, which starts playing activity. This approach defines play as waste or realization of imbued subjective forces since it takes the dynamic aspect of the game in isolation from its content.

3. K. Buhler (2013, p. 14). A feature of his approach is that functional satisfaction is taken as the main motive of the game, that is, organic pleasure from the action itself, regardless of the result. Therefore, the real content of the action is neglected; it is reflected in a certain emotionally effective colour.

4. Z. Freud (1989, p. 378) through the explanation of game as a form of realization of desires squeezed out by a person from his own life since in the game something is often played out and experienced that cannot be realized in everyday life.

5. A. Adler (2011, p. 88) - because of her understanding as an indicator of the inferiority of the subject, who runs away from reality, to which he cannot adapt.

6. L. Vygotsky (2004, p. 217) justifiably asserts that it is vital for the child to create a fictitious (contrived) situation in which this action plays a particular role. However, this cannot be the basis for understanding the game, according to D. Uznadze (2000, p. 195).

In any game, there are specific rules, a kind of semantic space. The main task of M. Heidegger's (2008) philosophy is seen not in redefining the concept of being, which would mean a return to metaphysics, if not in indicating a kind of experience in which being can become "accessible" to man (p. 7). And this kind of experience becomes a game (Sidorenko, 2007, p. 29). Dasein, being existential, is dependent on tradition, on everyday conventions. Being, as such, is devoid of any dependence. A person, as an inquiring being, who understands his temporality being Dasein, and not das Man, takes the path of freedom, where he exists according to the rules of the game (Heidegger, 2014, pp. 29-36).

In analytical philosophy, an attempt to understand the problems of play was undertaken by B. Sweets, who tried to give a rigorous definition of this phenomenon, contrary to L. Wittgenstein's (2009) assertion that "play" cannot be defined (p. 248). B. Suits offers the following interpretation: playing a game means overcoming unnecessary obstacles for the sake of the activity that they create. For example, in basketball, the goal is to throw the ball into a small ring; the players accept as something necessary the presence of opponents and the requirements for dribbling (no jogging, double dribbling, etc.). This is not done 
because passing the ball through the ring is in itself a valuable achievement (Kretchmar, 2012, p. 102). If that were the case, we would just walk into an empty basketball court with a stepladder. Instead, we essentially adopt an arbitration goal (achieving something within certain constraints) to create a new activity. Thus, playing games changes the usual balance of means and ends. In everyday life, we choose means for an end in itself. In playful circumstances, on the other hand, we choose an arbitrary goal to achieve it by certain means. This leads to the main thesis of B. Suits (2005) that games are the goal of life (p. 23). This is what his argument looks like: if we imagine a utopia, we imagine it free of all problems. In that case, we could also waste our time. How can we do without playing games?! And if games are the only activity in utopia, then they should be the goal of life. All practical activity, which we can call work, strives for self-elimination, the philosopher considers. Medicine, for example, seeks to eliminate the disease, which in turn will eliminate the need for medical practice. In this regard, some authors express the bold idea that even art presupposes a practical purpose: to calm the heart's worries, which would also be unnecessary in utopia (Nguyen, 2017, p. 16). Play, on the other hand, does not tend to self-destruction - and therefore can carry the purpose of life as a burden.

It may seem that philosophers have no unified position on the essence of the game. However, this would be a superficial conclusion. Despite the different vocabularies and metaphors used by the authors, it is possible to single out some general and essential properties of the game, latently recognized by every thinker. So, one can single out such properties of the game as non-utilitarianism, irrationality, the presence of rules, aesthetics, and the predominance of the child over the adult.

Having completed a short literary review, we would like to return to the problem identified at the beginning of the study: how does Kyrgyzstan relatively successfully reproduce the tradition, despite the political transformations of recent centuries and the global trends of globalization? To answer this question, we think it is reasonable to consider the game and its philosophical components in the context of the development of Kyrgyz society, having considered the key historical milestones of the latter.

\section{Main Part}

One of the characteristic differences between the Middle Ages and the present is the almost complete absence of the phenomenon of childhood (Aries, 1996, p. 13). The child, already 14 years old, performed all the social functions of an adult. This could not but affect the role of the game in this time period. It was considered exclusively from a pedagogical perspective. In medieval philosophy, based largely on the thoughts of Plato, Aristotle, the Stoic school, the play was seen as an educational tool. In the early Middle Ages, Augustine the Blessed's idealistic interpretation of the game was proposed, connecting the game aspect with spiritual activity. According to the philosopher, play is twofold since spirit structures matter (St. Augustine, 2004, p. 216).

The nomadic life has had a strong impact on the history and culture of Kyrgyzstan. In the Middle Ages, the Kyrgyz were divided into clans - "tags", there was a tribal organization "Budun"; later, the tags were transformed into the socalled "bugs", which included settlements of various clans. At the head of the "bug" was the lord - the run, who carried out the usurpation and disposed of everything. The pagan beliefs of those times were characterized by the cults of Earth and Water (Mamytbekov, 2017, p. 44). The harsh living conditions left their mark on the games of the Kyrgyz of that time. The following games are indicative: Kok-Boru - an equestrian game, where teams of eight, consisting of riders, fight for the carcass of a goat; Ordo is a game in which you need to overthrow the khan, developing intelligence and strategic abilities (Tashbaeva, 2012, p. 72). Thus, in the Middle Ages, the 
game was the personification of preparation for adulthood, the beginning of the formation of a young nomad, ready to conquer the endless steppes.

The changes in ethnic culture that are currently taking place are mainly due to the process of globalization. A. Kochkunov points out in this regard that "ethnic traditions have exceptional vitality. Having arisen at a certain stage of historical development, having passed a difficult, thorny path, they can transform, adapt to new conditions and maintain their relevance. In the conditions of modern life and culture, you can find various phenomena, the origins of which go back to deep and not so deep antiquity" (Kochkunov, 2013, p. 5).

Having become part of the Russian state, the Kyrgyz, in fact, for the first time in their entire history spanning several millennia, collided with a completely new and unknown European civilization represented by Russia. The entry of Kyrgyzstan into the Russian Empire led that the Kyrgyz people were involved in world history (Altymyshbaev, 2015, p. 101). Russia, in turn, as a European power, tried to keep up with the philosophical thought of Western Europe. In the enlightened European philosophical thought of new and modern times, the aesthetic role is added to the educational role of play. So, I. Kant, speaking about aesthetics and art, highlights the play of imagination and reason. The essence of the latter is to provide pleasure (Kant, 2009. P. 117). In the philosophy of F. Schleiermacher, play appears as a field of morality associated with art and friendship. In the sphere of play, a person harmoniously realizes his individuality. Also, the game develops intellectual abilities (Schleiermacher, 2008, p. 15). The ancient understanding of fire as a logos by F. Schlegel is transformed in the way that in place of fire, a game is put, interpreted as a universal principle of being. Art is seen as an echo of the endless world game (Schlegel, 1991, p. 29). F. Nietzsche's concept largely repeats the idea of F. Schlegel: a representative of the philosophy of life interprets art as something that imitates the game of the universe. The superman in the paradigm of F. Nietzsche (2020), being a projection of a child, is so overwhelmed that he plays with everything that was inviolable in the entire preceding culture from an excess of power (p. 134).

We would like to dwell in more detail on the game component of the pre-wedding relationship between the bride and groom at this historical stage. The "tok mok saluu" game began with the appearance of a relative of the bride (daughterin-law) with a twisted piece of cloth. The Kyrgyz believed that the contact of a towel or a segment of tacni with the back of the groom's friend frees them from impure forces (Dononbaev, 2008, pp. 196-207). Another of the roles of the groom's friend was to highlight the virtues of the daughter-in-law through songs. Then "both went to the middle of the yurt and, standing with their backs to each other, weaved their arms outstretched to the sides, after which they leaned back and kissed" (Ubukeev, 2014, p. 179). These actions were a kind of preparatory stage before the rite of "zhar korushturuu", which means a date with the beloved. On this date, the spouses sat with their backs to each other, and with the support of relatives and guests, kissed, leaning back and crossing their arms (Kochkunov, 2010, pp. 36-58). As the game continued, it could acquire frank content and the songs already carried erotic overtones. It is believed that the genesis of "tok mok saluu" is counted from the time of the existence of group marriage, which then began to bear a ritual and ceremonial character (Simakov, 1984, pp. 182-184). After these events, a joint meal began, before which everyone got up and sat down the groom and the bride, and the bride was seated higher than the groom (Ugdyzhekov, 2003 , p. 60). Sitting next to each other, the spouses tried to put knee pressure on each other's knee. This game had a symbolic status - the one who wins and whose knee is higher will dominate the family (Urmanbetova, 2014, p. 128). This method of social interaction, of course, has its roots deep in history and reflects the echoes of 
the struggle between maternal and paternal families for leadership (Bayalieva, 1972, p. 76). Thus, we see a large-scale social organism, the main task of transferring genes. It can be concluded that the game acts as a kind of social mediator among the younger generation, contributing to the growth of pairs of married couples, which is necessary for the reproduction of subsequent generations.

The February Revolution of 1917 stopped eradicating the Kyrgyz ethnos, accompanied by its expulsion from their native lands. Then the October Revolution happened, along with which a new stage began in the history of all the peoples of the Russian Empire, including the Kyrgyz people. Globalization began for the Kyrgyz people from the moment the territories that belonged to the Kyrgyz tribes entered the Russian Empire (Elebaeva, 1995, p. 280). This time is characterized for the Kyrgyz by the beginning of existence within the framework of industrial civilization. Nevertheless, the most fundamental and largescale social transformations in Kyrgyz land took place during the Soviet era. Thanks to the Soviet Union, the Kyrgyz people managed to recreate the lost statehood. Unfortunately, this was done not by nomadic ones, like all previous historical periods, but in modernist forms. For several decades, the main modern forms of state institutions were created. Besides, the Soviet government provided conditions for the formation of a single Kyrgyz nation, which was supposed to eradicate the tribal, clan levels of ethnic identity, which are certainly much closer to the ethnic tradition than the national level of identity.

With the collapse of the Soviet Union, a new historical milestone for the Kyrgyz people began. This period is characterized by the acquisition of political sovereignty and entry into world history as an independent political force. Fortunately, in our opinion, the Soviet modernization did not reach its logical conclusion in Kyrgyzstan. Before collectivization, Kyrgyzstan was a country of nomads. The Kyrgyz lived not in cities but yurts and were engaged in hunting and cattle breeding. Of course, the arrival of the communists with their large-scale projects, in particular collectivization, brought about changes in the way of life of the nomads. The construction of cities and villages made many Kyrgyz people settled. However, as we have already noted above, several decades are not enough for the destruction of the traditional elements of the life of an ethnic group, and not all nomads adopted a new way of life. Kyrgyzstan still has an important cultural resource in the form of people, some of whom have always led a nomadic lifestyle, and some returned to it after gaining independence after secession from the USSR in 1991. Today they are settled in the mountains on the territory of Kyrgyzstan.

Thus, the modern stage of life of the Kyrgyz is characterized by mutually exclusive processes of cultural assimilation and dissimilation. Assimilation leads to a decrease in the role of play in the family sphere of the social organism. In the first quarter of the $21^{\text {st }}$ century, Kyrgyzstan is in a disequilibrium position, at a point of bifurcation, when cultural and social processes can follow a completely unpredictable scenario. In our opinion, an important strategic advantage of the Kyrgyz people is its long-term nomadic way of life, which has enormous potential for preserving national family game traditions.

For a nomad, the idea of combining a man and a horse inside a "machine of desires" is immanent, which, together with other nomads, is a structural part of the horde - a willing mega-machine. The nomadic way of existence creates an open space of being through expansion, while the goal of the state is to consolidate territories by establishing boundaries and splitting the space belonging to it into segments (Ignatov, 2016, p. 40). The existence of a nomad is due to constant movement, but a nomad, unlike a state, fixes territories by constantly moving, thereby re-opening space each time. A feature of the nomadic movement of the Kyrgyz is not a simple movement from point $\mathrm{A}$ to point $\mathrm{B}, \mathrm{C}$, etc. In the existentialontological sense, a nomad does not exist outside 
of the movement, and it is immanent to him. He does not move on the way to or from the house; as a sedentary person, he moves with the house. Thus, the nomad is in a certain sense motionless.

J. Deleuze and F. Guattari (1986), typologizing the games of different cultures according to the method of dividing space, oppose chess and the game of go (p. 217). Chess implies the organization of space (the structure of a well-defined field of the playing board with a system of positioning of figures) and a strictly defined correspondence of constantly fixed figures to their possible positions - to places of deployment in a closed territory (Fominykh, 2018, pp. 70-72). Go, on the contrary, presupposes the absence of rigidly fixed territorialization and deterritorialization of space. In this game, qualitatively indistinguishable pieces are scattered on a surface without clear boundaries. This scattering sets the topology of the nomadic distribution of individual units with the possibility of self-reunification, which radically differs from the fixed sedentary distribution. Kyrgyz table games are also arranged according to the nomadic principle. Here we can cite the example of "Topo Basman" - a game with apricot bones and "Zuuldak" - a game with buttons. It is characteristic that the basic structural units of these games (bones and buttons), as well as the pieces of go, are qualitatively indistinguishable. Thus, the nomadic project of the spatial organization of the Kyrgyz people is as unconventional as possible in comparison with the Soviet project or the modern post-Soviet space. According to J. Deleuze and F. Guattari (1986), Western culture is based on the concept of movement along the axial vector, in contrast to the nomadic worldview with movement as dispersed dispersion: "we are writing history ... from the point of view of a person leading a sedentary lifestyle... History has never understood the nomads, the book has never understood the outside" (p. 256). Now we understand much more clearly the way of the Kyrgyz world perception, which is based on total detachment to the centre: space does not have a point that could claim to be the dominant one (Braidotti, 1994, pp. 15-17).

Usually, many researchers see in a game an exclusively childish principle. We would like to draw attention to the presence of the female eidos in it (using the language of Plato). It is known that the following division has been fixed in the philosophical tradition: the male component in culture is considered as rational, logically structured, and the female principle as something irrational. The irrationality of women and the irrationality of the game are closely intertwined. Thus, in our opinion, the component of femininity in play is of key importance. The female "eidos" in this section is very similar to the system of the nomadic Kyrgyz way of life, opposing the logocentric male Western image of structuring space.

Rhizomaticity, i.e. the decenteredness of the environment, has a huge potential for self-organization: "The rhizome can be torn, broken ... rebuild to another line" (Deleuze \& Guattari, 1987, p. 18). In this case, the cause of the transformations is not something external but the internal potentials inherent in the system itself. In this case, we are talking about a synergistic interpretation of instability in open systems, the concept of which is actively used in modern natural science (Haken, 2006, p. 7).

Thus, the game is a part of the daily activities of the Kyrgyz at all stages of the historical process and the life of individual people. Using the model of E. Erikson (1993) as age periodization (p. 17), we can talk about the following stages: childhood, adolescence, youth, adulthood, old age. In childhood, a game performs a developmental function ("topo basman", "zuldak"), in youth, it prepares for the trials of a difficult nomadic way of life ("ordo", "kok-boru"). In youth and adulthood, the game acts as a kind of social mediator, contributing to the compilation of pairs ("tok mok saluu"), in old age, the game is an element of heritage when a generation wise with life experience passes on the tradition through play practices. 


\section{Conclusion}

The game is a social formation more ancient than culture and civilization. An archaic culture arose from the game and laid the foundation for man in his modern understanding, and also, a game is what the development of the worldhistorical process continues to this day. Speaking about the family gaming traditions of the Kyrgyz and their stability, it is certainly necessary to take into account the centuries-old culture of the nomadic lifestyle of this ethnic group. The nomadic and rhizomatic structure of Kyrgyz society played a decisive role in the sustainability of the transmission of family traditions through the game component. The phenomenon of the game consists of the involvement of the player, his sincere interest in what is happening, escape from the routine. Games of the Kyrgyz people have all these properties. In many ways, they, being part of the biosocial organism, contributed to the survival and reproduction of the Kyrgyz ethnos for most of history. In childhood, the game performs a developmental function; in youth, it prepares for the trials of a difficult nomadic way of life. In youth and adulthood, the game acts as a kind of social mediator, contributing to the pairing. In old age, play is an element of heritage when a generation wise with life experience passes on the tradition through play practices. We also revealed the presence of a female principle in the game. Being irrational, the opposite of phalloand logocentrism, it has a powerful potential for self-organization and a way out of crisis situations in the family, which indicates the most important role of a woman and her ability to overcome crises both in the local and global scales of the modern world.

Modern Kyrgyzstan is at a non-equilibrium point of its development when cultural and social processes can follow a scenario that is difficult to predict. Thousands of years of life experience of the people, socio-economic ties, cult actions, tribal relations could not disappear in several decades and even centuries. However, of course, these days, there is a specific transformation and modernization of these elements. In our opinion, a significant strategic advantage of the Kyrgyz people is its long-term nomadic way of life, which has enormous potential for preserving national gaming family traditions. Consequently, a further detailed study of the issue raised in our article is necessary, already directly entirely devoted to the modern agenda and the challenges thrown down to the preservation of Kyrgyz gaming traditions. It is also worth noting that little has been studied: the traditional Kyrgyz society, the culture of nomadism and nomadism, the internal architecture of the tribal association, its social strata. These questions are of interest for our future work.

\section{References}

Adler, A. (2011). The practice and the theory of individual psychology. Eastford: Martino Fine Books.

Altymyshbaev, A. A. (2015). Ocherk razvitiya obshchestvenno-politicheskoi mysli v dorevolyucionnoi Kirgizii (Essay on the development of socio-political thought in pre-revolutionary Kyrgyzstan, in Russian). Bishkek: Ilim.

Aries, F. (1996). Centuries of childhood. London: Pimlico.

Bakhtin, M. M. (1965). Tvorchestvo Fransua Rable $i$ narodnaya kul'tura srednevekov'ya i renessansa (François Rabelais' creativity and folk culture of the Middle Ages and Renaissance, in Russian). Moscow: Mysl'.

Barthes, R. (1975). The pleasure of text. New York: Hill and Wang.

Baudrillard, J. (2020). The system of objects. Brooklyn: Verso.

Bayalieva, T. D. (1972). Doislamskie verovaniya i ikh perezhitki u kirgizov (Pre-Islamic beliefs and their vestiges among the Kyrgyz, in Russian). Frunze: Ilim.

Berlyand, I. E. (1992). Igra kak fenomen sozna- 
niya (Play as a phenomenon of consciousness, in Russian). Kemerovo: Alef.

Berne, E. (1996). Games people play: The basic handbook of transactional analysis. New York: Ballantine Books.

Braidotti, R. (1994). Nomadic subjects: Embodiment and sexual difference in contemporary feminist theory. New York: Columbia University Press.

Buhler, K. (2013). The mental development of child. Abingdon: Routledge.

Burke, E. (2004). Reflections on the revolution in France. Boston: Digireads.com.

Caillois, R. (2001). Man, play and games. Champaign: University of Illinois Press.

Deleuze, G. (1996). What is philosophy? New York: Columbia University Press.

Deleuze, G., \& Guattari, F. (1986). Nomadology: The war machine. Los Angeles: Semiotext(e).

Deleuze, G., \& Guattari, F. (1987). A thousand plateaus: Capitalism and schizophrenia. Minnesota: University of Minnesota Press.

Derrida, J. (1998). Of grammotology. Baltimore: Johns Hopkins University Press.

Dononbaev, A. D. (2008). Epos "Manas": sud'ba naroda $v$ zhizni eposa $i$ sud'ba eposa v zhizni naroda (Epic "Manas": The people's fate in the epic's life and the epic's fate in the people's life, in Russian). Politika i obshchestvo (Politics and Society, in Russian), 3, 62-77.

Elebaeva, A. B. (1995). Razvitie mezhetnicheskikh otnoshenii v novykh nezavisimykh gosudarstvah Central'noi Azii (Development of interethnic relations in the newly independent states of Central Asia, in Russian). Bishkek: Ilim.

Elkonin, D. B. (1999). Psihologiya igry (Game psychology, in Russian). Moscow: VLADOS.

Erikson, E. (1993). Childhood and society. New York: W. W. Norton \& Company.
Fink, E. (2016). Play as symbol of the world. Bloomington: Indiana University Press.

Fominykh, M. V. (2018). Shakhmaty kak social'no-kul'turnyi fenomen (Chess as a socio-cultural phenomenon, in Russian). Vestnik of Moscow City University (in Russian), 1(25), 68-76.

Foucault, M. (2006). History of madness. Abingdon: Routledge.

Freud, S. (1989). Introductory lectures on psychoanalysis. New York: Liveright.

Gadamer, H. (2008). Philosophical hermeneutics. Berkeley: University of California Press.

Groos, K. (2020). The play of man - psychological purpose of child's play. New York: Musaicum Books.

Haken, H. (2006). Information and self-organization: A macroscopic approach to complex systems. Berlin: Springer.

Heidegger, M. (2008). Being and time. New York: Harper Perennial Modern Classics.

Heidegger, M. (2014). Introduction to metaphysics. Bloomsbury: Yale University Press.

Hesse, H. (2002). The glass bead game: (Magister Ludi) a novel. London: Picador.

Huizinga, J. (2014). A study of the play-element in culture. Eastford: Martino Fine Books.

Hutchinson, P. (1984). Games authors play. Abington: Routledge Kegan \& Paul.

Ignatov, M. A. (2016). Nomadologiya Zh. Deleza kak versiya setevoy metodologii (Nomadology of Zh. Delez as version of network methodology). Nauka. Iskusstvo. Kul'tura (Science. Art. Culture, in Russian), 3(11), 38-43.

Jaspers, K. (1971). Philosophy of existence. Philadelphia: University of Pennsylvania Press.

Kant, I. (2009). Critique of judgement. Oxford: Oxford University Press.

Kochkunov, A. (2010). The ritual of hospitality 
in traditional and modern Kyrgyz culture. Anthropology of the middle east. New York: Berghahn Books.

Kochkunov, A. C. (2013). Etnicheskie tradicii kirgizskogo naroda (sociokul'turnye aspekty i nekotorye voprosy genezisa) (Ethnic traditions of the Kyrgyz people (socio-cultural aspects and some issues of genesis), in Russian). Bishkek: NPO "Kyrgyz ZHer".

Kretchmar, S. (2012). Competition, redemption, and hope. Journal of the Philosophy of Sport, 39(1), 101-116.

Lacan, J. (1998). The seminar of Jacques Lacan: The four fundamental concepts of psychoanalysis. New York: W. W. Norton \& Company.

Lotman, Yu. M. (1998). Ob iskusstve: struktura khudozhestvennogo teksta (About art: The structure of a literary text, in Russian). Saint Petersburg: Iskusstvo.

Mamytbekov, Z. Ch. (2017). Otrazhenie zhizni i bor'by kirgizov $v$ epose "Manas" (Reflection of the life and struggle of the Kyrgyz in the epic "Manas", in Russian). Bishkek: KRSU.

Miller, S. (1997). Psikhologiya igry (Game psychology, in Russian). Saint Petersburg: Universitetskaya kniga.

Morgenstern, O., \& Neumann, J. (2020). Theory of games and economic behavior. New York: Golden Keys Success.

Nguyen, C. (2017). Philosophy of games. Philosophy Compass, 12(8), 15-26.

Nietzsche, F. (2020). The gay science. New York: Dover Publications.

Plato (1997). Complete works. Indianapolis: Hackett Publishing.

Rubinstein, S. L. (1989). Osnovy obshchei psikhologii (Fundamentals of general psychology, in Russian). Moscow: Pedagogika.

Schiller, F. (2016). On the aesthetic education of man. London: Penguin Classics.
Schlegel, F. (1991). Philosophical fragments. Minneapolis: University of Minnesota Press.

Schleiermacher, F. (2008). Hermeneut criticism. Cambridge: Cambridge University Press.

Sidorenko, I. N. (2007). Igra kak osnovnoi vid opyta raskrytiya bytiya $\mathrm{v}$ filosofii $\mathrm{M}$. Khaideggera (Play as the main type of experience of disclosure of being in the philosophy of M. Heidegger, in Russian). Filosofiya i social'nye nauki (Philosophy and Social Sciences, in Russian), 4, 29-32.

Simakov, G. N. (1984). Obshchestvennye funkcii kirgizskikh narodnykh razvlechenii $\mathrm{v}$ konce 19 - nachale $20 \mathrm{vv}$. Istoriko-etnograficheskie ocherki (Public functions of Kyrgyz folk entertainment in the late $19^{\text {th }}$ - early $20^{\text {th }}$ centuries Historical and ethnographic essays, in Russian). Leningrad: Nauka.

Spencer, H. (2019). First principles. Chicago: Independently published.

St. Augustine (2004). City of God. London: Penguin Classics.

Suits, B. (2005). The grasshopper: Games, life and utopia. Peterborough: Broadview.

Tashbaeva, K. I. (2012). Kul'tura rannikh kochevnikov Tyan'-Shanya i Alaya (The culture of the early nomads of the Tien Shan and Alai, in Russian). Bishkek: Maga.

Ubukeev, M. A. (2014). "Manas": epicheskaya kul'tura kirgyzov (Manas: The epic culture of the Kyrgyz, in Russian). Bishkek: Muras.

Ugdyzhekov, S. A. (2003). Semeino-brachnaya struktura kyrgyzov VI-XIII vv (Family and marriage structure of the Kyrgyz of the $6^{\text {th }}-13^{\text {th }}$ centuries, in Russian). Vestnik HGU im. N.F. Katanova (Bulletin of Khakassia State University named after N.F. Katanova, in Russian), 3(3), 
59-63.

Urmanbetova, Zh. K. (2014). Kul'tura kyrgyzov v proekcii filosofii istorii (Kyrgyz culture in the projection of the philosophy of history, in Russian). Bishkek: Ilim.

Uznadze, D. N. (2000). Teoriya funkcional'noi ustanovki (Functional attitude theory, in
Russian). Moscow: Izdatel'skii dom Shalvy Amonashvili.

Vygotsky, L. S. (2004). Psikhologiya razvitiya rebenka (Child development psychology, in Russian). Moscow: Eksmo.

Wittgenstein, L. (2009). Philosophical investigations. Hoboken: Wiley-Blackwell. 